\title{
Durkheim og Religionens fremtid: En oversættelse af en tale af Émile Durkheim med indledning
}

\author{
KATRINE FRØKJÆR BAUNVIG
}

\begin{abstract}
ENGLISH ABSTRACT: The present article marks the centennial of Émile Durkheim's speech "L'avenir de la religion" which was transcribed and published in 1914. Following an introductory sketch of (primarily) Danish academic research into Durkheim's thoughts and writings I will present a translation into Danish of the speech.

DANSK RESUME: Denne artikel markerer hundredåret for Émile Durkheims afholdelse af talen "L'avenir de la religion", som blev nedskrevet og udgivet i 1914. Efter en indledende skitsering af (hovedsageligt) den danske akademiske læsning og forskningen $i$ Durkheims tænkning og forfatterskab følger en oversættelse af talen til dansk.
\end{abstract}

KEYWORDS: Durkheim; Durkheim-research; 1914; translation

2014 er et jubelår. Alene i Danmark markeres årsdagene for skolereformen og tabet af Norge 1814, ligesom selvfølgelig nationaltraumet 1864 mindes ved en lang række arrangementer og med en lang række udgivelser. Men i en europæisk sammenhæng er det første verdenskrigsbegyndelse 1914, der står som den afgørende begivenhed. Markeringen af 1914 er også afsættet for denne artikel. Siden Stefan Zweigs Die Welt von Gestern udkom i 1942, har det været almindeligt at beskrive overgangen fra 1913 til 1914 som en grænse i tid og verdensbillede: afslutningen på 'det lange 19. århundrede' - Eric Hobsbawms betegnelse for den periode, som indledtes af den franske revolution 1789. Grundopfattelsen i Florian Illies 1913. Der Sommer des Jahrhunderts (2012) er den samme. På dokufiktiv vis opregnes det kunstneriske, politiske, filosofiske, videnskabelige og sociale overskud, der i kraft af en række konkrete personer befandt sig i eu- 
ropæiske og nordamerikanske metropoler med særlig vægt på Wien, München og Berlin for lidt mere end hundrede år siden, og som skulle komme til at forme det 20. århundrede. Illies er et eksempel på en mere generel tendens til, at man i disse år er optaget af den historie og de forestillinger, der former de nationale og transnationale fællesskaber, mennesker indgår i. De rene, runde tal indbyder i sig selv til at gøre status. Som Marcel Proust jager vi tabt tid, mening og identitet. Det gælder i en bred, offentlig og kulturel sammenhæng. ${ }^{1}$ Men det er også tilfældet i en mere specifik, akademisk kontekst, hvor begreber som fx 'kollektiv erindring' står stærkt i den humanistiske forskning; ${ }^{2}$ tilsvarende er hukommelse som et helt centralt kognitivt fænomen genstand for en mængde studier af neuro-medicinsk og psykologisk karakter; det er med andre ord centralt placeret i selve forståelsen af, hvad man interesserer sig for inden for kognitive videnskaber som sådan.

Disse indledende betragtninger er relevante, fordi denne artikel i løs og bred forstand interesserer sig indholdsmæssigt for hukommelse som tema, og fordi den er en optakt til en oversættelse af en tekst, der i år fylder de 100 år. Ligeså vigtigt er imidlertid, at den samtidig i sig selv kan opfattes som en art 'hukommelses-handling': den kan betragtes som et forsøg på at fiksere et moment i religionsvidenskabens formative fag-fortid. Dette moment er Émile Durkheims religionsteori, og fordi det ikke lykkedes mig at fejre hundredåret for udgivelsen af hovedværket Les formes élémentaires de la vie religieuse (FE), som udkom i 1912, griber jeg her anledningen til at udgive oversættelsen af et foredrag, han holdt i 1914, med titlen "L'avenir de la religion", dvs. 'Religionens fremtid'. Teksten kondenserer belejligt væsentlige aspekter ved teorien i FE og tydeliggør samtidig det kulturelle klima, Durkheims religionsforskning voksede op i. Men før jeg går videre i introduktionen, vil jeg fremhæve endnu en omstændighed, som gør det relevant at trykke oversættelsen netop nu og i netop dette tidsskrift.

\section{Dansk Durkheim}

Allerede i Durkheims levetid blev han oversat til andre sprog. FE udkom eksempelvis i en engelsk oversættelse i 1915 ved J.W. Swain. ${ }^{3}$ Men man viste ham også interesse i dansk sammenhæng. Durkheims og Denis' reaktion på og analyse af første verdens-

\footnotetext{
De førnævnte, såkaldt 'konmemorative' begivenheder til årstalsmarkering er indlysende eksempler. Men der gives også andre mere indirekte, som viser, at tendensen samtidig har en mere individuel-psykologisk side. Et oplagt eksempel på det er Karl Ove Knausgaards autofiktions-projekt i seks bind, Min Kamp.

2 Jan og Aleida Assmanns forfatterskaber og Frances Yates' er nogle få, men indlysende repræsentanter for dette felt.

3 Swains oversættelse er åbenbart optrykt i stort antal, siden den stadig ses brugt, skønt den sine steder var misvisende og sidenhen er erstattet af to langt bedre, moderne oversætelser, Karen E. Fields' fra 1995 på The Free Press, New York, og Carol Cosmans fra 2001 på Oxcford University Press. Fields oversættelse er et mesterværk og burde være den autoritative; Cosmans er en forkortelse, men bekvem og brugbar bl.a. i universitetsundervisning.
} 
krigs udbrud, "Hvem har villet Krigen? Krigens Oprindelse iflg. Diplomatiske Dokumenter", blev eksempelvis allerede få måneder efter den franske udgivelse i 1915 oversat af Hjalmar Hansen og optaget i serien Studier og Dokumenter angaaende Krigen. Året efter forekom noget tilsvarende med en anden krigsrelateret tekst: "'Deutschland über alles'. Tysk Mentalitet og Krigen", som blev oversat af E. Lüb-schitz. Men interessen var imidlertid begrænset til netop disse typer af tekster - til det, man kunne kalde Durkheims mere almene, offentlige virke. Det akademisk-videnskabelige arbejde var altså ikke udbredt i Danmark i Durkheims samtid. I den forstand ligner den danske reception af Durkheim den generelle reception uden for Frankrig, hvoraf henholdsvis den engelske og amerikanske er de mest betydningsfulde. Først i 1930'erne og 1940'erne tog forskere uden for Frankrig Durkheims forfatterskab målrettet og mere (men ikke meget) systematisk op (Fournier 2007, 803-4; Lukes 1972, 588-590). A.R. Radcliffe-Brown, Meyer-Fortes og E.E. Evans-Prichard og deres 'social anthropology' er oplagte repræsentanter for den engelske læsning eller brug. Tilsvarende er Talcott Parsons og R.K. Merton væsentlige at fremdrage som eksempler på en amerikansk Durkheim-inspiration.

Også i Danmark falder begyndelsespunktet i 1930'erne. Mere præcist begynder det med Aarhus-sociologen Svend Ranulfs artikel om Durkheim, Auguste Comte og Ferdinand Tönnies, "Scholarly Forerunners of Fascism" fra 1939. Denne artikel er stadig genstand for (international) forskningsmæssig interesse (se eksempelvis Turner 2007). Dens hovedargument var, at Comte, Durkheim og Tönnies gødede jorden for fascismen, fordi de hver især på slagkraftig vis satte ord på den opfattelse, at deres respektive samfund var på katastrofekurs: For dem alle tre var det et omkvæd, at individualistiske og liberalistiske tendenser havde vokset sig stadig stærkere i 1800-tallet og dermed havde svækket national fællesskabsfølelse, solidaritet og sammenhængskraft (Ranulf 1939, 33-34). Med denne kategorisering af Durkheim som (kultur)konservativ tænker lægger Ranulf sig på linje med den samtidige franske Durkheim-reception. ${ }^{4}$ Det politiske klima i tredivernes Tyskland og Italien var naturligvis bagtæppet for Ranulfs betragtninger. De er interessante, fordi de implicit antyder et aspekt ved Durkheims teori, som jeg andetsteds har redegjort for, at man bør tolke ind i en tysk 'åndshistorisk' tradition, der kan føres tilbage til Johann Gottfried Herders begreber om Volk og Volksgeist (Baunvig 2013, 156ff). Ranulf foregreb således - skønt muligvis med en skæv emfase på de politisk-normative elementer i Durkheims sociologiske 'projekt' en interesse for Durkheims såkaldt sene forfatterskab og dets slægtskab med tyske tænkere, som man inden for de sidste 10-15 år i Durkheim-forskningen er begyndt at interessere sig stadig mere for. Dette skal jeg vende tilbage til. På dette punkt skal jeg imidlertid kort skitsere en anden tidlig dansk Durkheim-forsker: Christian Petersen.

I Paul Nizans betydningsfulde generationsopgør "Les Chiens de garde" lyder det fx således: "Durkheim accomplit enfin dans la mort la tâche de conservation bourgeoise qu'il avait entreprise dans la vie" (1932, 98). 
I 1943 forsvarede højskolelæreren Christian Petersen den sociologiske afhandling Émile Durkheim: En historisk kritisk studie: Med særligt hensyn til hans almindelige Sociologi eller Samfundssyn. ${ }^{5}$ I titlen bør man læse et eftertryk på 'kritisk'. Petersen introducerer generelt til Durkheims tænkning, men fokuserer derudover særligt på Durkheims tidlige forfatterskab, dvs. før spørgsmålet om religion blev så centralt, som det blev i FE. Det vil sige, at det på den ene side er hans metodiske og teoretiske grænsedragning i forhold til beslægtede fags genstandsområder, som Petersen samler under betegnelsen 'Durkheims samfundsfilosofi' (118-183), og på den anden side særinteressen i selvmordet og arbejdsdelingen som signifikante fænomener, som Petersen præsenterer som 'Durkheims specielle sociologi' (184-218). Den gennemgående tone er skeptisk-diskuterende, og den sammenfattende vurdering er, at Durkheim "løber fast i nogle uholdbare paradoksale paastande" (242). Kort sagt mener Petersen, at Durkheim vil både blæse og have mel i munden. Han vil fremskrive samfundslivets stadige individualisering og liberalisering, samtidig med at han ønsker at beskrive 'det sociale' som en grundlæggende determinerende kraft (ib.). Denne kritiske bedømmelse til trods blev Durkheim fast inventar i samfundsvidenskabelige pensa. Herom vidner først og fremmest de danske oversættelsere af den del af forfatterskabet, som beskæftiger sig fænomener som arbejdsdeling og selvmord. De første oversættelser blev udarbejdet i 1970'erne, og andre er løbende fulgt. Valget af tekster til oversættelse afspejler et fokus på de positivistiske og materialistiske elementer i Durkheims tænkning, som har været den eneste almindelige læsning - også på internationalt plan - indtil først i dette årtusind.

Durkheim, hvis professorater hhv. i Bordeaux og ved Sorbonne i Paris begge havde tyngdepunkt i pædagogik, ikke i sociologi, har også spillet en rolle i den danske pædagogik-forskning. K. Grue-Sørensens Durkheims teori om disciplinen fra 1956 må opfattes som det første specifikt pædagogisk interesserede studie i Danmark. Interesse har man i nogen grad fastholdt, som det ses af en stabil udgivelsesstrøm af forsknings- og lærebogslitteratur (jf. fx Lieberkind 2010, Olesen 2007, Sørensen 2012).

Den religionsvidenskabelige omgang med Durkheims teorier tegner derimod et lidt andet mønster. Man fristes til at tale om en sen, men eksplosiv stigning i opmærksomhed i forfatterskabet og i afledte eller relaterede interessefelter. Udviklingen begyndte i forrige årti og tog ikke mindst afsæt i holdet omkring Religionsvidenskabeligt Tidsskrift, hvoraf Hans Jørgen Lundager Jensen nødvendigvis bør fremhæves særskilt. Han skrev i en række artikler (jf. 2003, 2005, 2008a, 2008b, 2009) i samklang med den vending, som jeg allerede har antydet har fundet sted i den internationale forskning: nemlig overgangen fra fokus på det såkaldt tidlige forfatterskabs positivistiske og materialistiske tendenser med centrale ord som struktur, institution og funktion til det sene forfatterskabs hermeneutiske og kultur-orienterede tendenser med nøgleordene

\footnotetext{
Jeg takker Tove Tybjerg for ved mit ph.d.-forsvar at minde mig om eksistensen af Petersens afhandling.
} 
ritual og repræsentation. ${ }^{6}$ Lundager Jensen placerer sig således mellem positioner som Jeffrey Alexander, Philip Smith og Ivan Strenski, der har sat sig for at fremskrive 'en ny Durkheim': At det der faktisk synes at være konsensus om, at man står med en ny eller genfunden Durkheim, indikeres alene af titlerne på de mange nyere udgivelser: The New Durkheim hedder således både Strenskis artikelsamling fra 2006 og Smiths og Alexanders indledning til The Cambridge Companion to Durkheim fra 2005. Den sidstnævnte har efterhånden etableret sig som en standardindføring i dels Durkheims forfatterskab og dels det tyvende århundredes Durkheimforskning. Hertil kommer Susan Stedman Jones' Durkheim Reconsidered fra 2001, W.S.F. Pickerings antologi Durkheim Today og senest Iver B. Neumanns Tilbake til Durkheim: Staten og Antropologien fra 2011.

Lundager Jensen har med sit arbejde særligt understreget Durkheims forståelse af 1) religion som et fænomen sui generis, 2) at religion og kultur i sidste instans er sammenfaldende størrelser, 3) at religionens og kulturens primære modus er semiotisksproglig, 5) men at de som kollektive enheder baserer sig på enkeltindividers (ikke mindst fysiske) deltagelse - med andre ord: på ritualer. 4) En beslægtet pointe er, at mennesker er homo duplex'er, der både består af biologi og kultur - og at mennesket først opnår sin egentlige menneskelighed på baggrund af en socialiseringsproces. Et underlæggende ønske hos Lundager Jensen synes at have været at råde bod på et forskningshistorisk hukommelsestab: at tildele Durkheim den retmæssige andel i det 20. århundredes 'cultural turn'7 samt at indse det potentiale, Durkheim besidder til at forbinde dele af forskningen, som specialiseringens centrifugalkraft ellers stille, men sikkert fjerner fra hinanden. Derfor betragter han: "Det er ikke underligt, at der for et par år siden kunne komme en bog med titlen Durkheim's Ghosts (Lemert 2006). Det er dette spøgelse, der kan forbinde kognition og kultur i religionsteorien" (2008b, 39).

Men efter denne skitse nu til sagen.

\section{Durkheims tale}

Durkheim deltog d. 18. januar 1914 i et arrangement afholdt af en forening for fritænkere og frie troende, som gik under navnet l'Union de libres penseurs et de libres croyants pour la culture morale (Fournier 2007, 831). Foreningen, som blev ledet af litteraten

6 I forskningen har dette 'Kehr-spørgsmål' dannet udgangspunktet for en del eksegese. Allerede i 1970'erne argumenterede Steven Lukes for en inddeling af forfatterskabet i to perioder; skiftet markeredes ifølge Lukes, da Durkheim blev universitetsansat ved Bordeaux i 1887 (1972, 421; Lacroix 1981). De fleste mener imidlertid i dag, at den afgørende vending fandt sted midt eller sidst i 1890'erne (Alexander 1988; Siegel 1987, Fournier 2005).

En fyldig redegørelse for denne amnesi må vi undvære her. Men årsagen gemmer sig først og fremmest i den engelsksprogede antropologi. Victor Turner og Clifford Geertz kan tjene som eksempler. Begge bærer tydelige durkheimianske præg, og deres arbejdsfelter skærer hovedtemaerne i Durkheims sene forfatterskab. Turners 'communitasbegreb' er således nært beslægtet med Durkheims 'effervescens', ligesom Clifford Geertzs religionsdefinition løber parallelt med Durkheims definition i FE. Men begge refererede kun i yderst begrænset omfang til Durkheims udgivelser (jf. Alexander 2005, 11-12). 
Émile Faguet og den socialistisk engagerede udannelsesembedsmand og akademiker Ferdinand Éduard Buisson, ønskede at udforske religiøse forestillingers betydning og virkning i en moral uden religiøse elementer (ibid.). Durkheim blev opfordret til at tale under selve arrangementet, fordi det var en del af dagens program, at Gustave Belot ville give en kritisk gennemgang Durkheims hovedværk Les formes élémentaires de la vie religieuse, der var udkommet et par år forinden, i 1912. Belot var en rationalistisk og erklæret ikke-religiøs filosofiprofessor ved lycée Louis-le-Grand i Paris. Han var interesseret i det nye forskningsfelt sociologi og positivt indstillet over for Durkheims arbejde (Pickering 2010). I 1913 blev Belot desuden ministerielt udpeget som ansvarlig for udviklingen af sekundærundervisningen i hele Frankrig (Chimisso 2003, 43), så også på dette punkt havde han en fælles interesse med Durkheim jf. professoraterne i Bordeaux og ved Sorbonne. Durkheims tale var ikke baseret på et forberedt manuskript. Den følgende oversættelse er derfor baseret på den transskription, som blev optaget i antologien Le sentiment religieux à l'heure actuelle, der udkom senere på året 1914. Antologien blev udgivet af Frank Abauzit, som også arrangerede konferencen. ${ }^{8}$

Durkheims tale er blevet oversat til engelsk af Jacqueline Redding, og den indgår i tekstsamlingen Durkheim on Religion, som W.S.F. Pickering redigerede og udgav i 1994 (p. 181-189). Men teksten har ikke fået den opmærksomhed, den fortjener. ${ }^{9}$ For den kan opfattes som en komprimeret, slagkraftig præsentation af to væsentlige elementer i Durkheims religionsteori: dels hans understregning af de religiøse fænomeners virkelighed og virkninger og dels hans forståelse af religionsforskerens metier som en hermeneutisk oversættelse af erkendelser, der allerede 'er til stede' i det religiøse genstandsfelt. Andre har grundigt redegjort for Durkheims syn på ritualets virkning. Jeg skal her i et kort intermezzo skitsere 'oversættelses-perspektivet'.

\section{Religionsforskningen som myteoversættelse}

"L'avenir de la religion" er en palindrom-tekst, som i første halvdel forklarer Durkheims teori for fritænkere og i sidste halvdel udlægger den for fritroende. Denne dobbeltmålgruppe gør teksten til et privilegeret udgangspunkt for undersøgelser af Durkheims forståelse af forholdet mellem religionsforskningen og dens genstand.

John Milbank har som kritik af Durkheims sociologiske projekt anført, at man bør opfatte den som "a theology, and indeed a church in disguise, but a theology and a church dedicated to promoting a certain secular consensus" (1990, 4). Denne kritik har været almindelig siden Paul Nizans fornævnte "Les Chiens de garde" fra 1932. Men

\footnotetext{
Abauzit var religionspsykologisk orienteret og oversatte William James' Varieties of Religious Experience til fransk (Miller 2005, 19).

9 Der er eksempelvis ingen referencer til teksten i The Cambridge Companion to Durkheim. Tilsvarende findes der ingen artikler i tidsskriftet Durkheimian Studies, som på titelniveau indikerer, at de beskæftiger sig med den.
} 
kritikken er skæv alene, fordi den er en kritik. Alligevel har Milbank fat i en indholdsmæssig rigtig point. Hvordan hænger det sammen?

Milbank har ret i den forstand, at Durkheim i sin forskningsmæssige omgang med religion åbner sig mod teologisk refleksion: Han ser en kontinuitet mellem de erkendelser, der udtrykkes i religionens symbolverden, normer og handlingspraksisser, og de rationelle forklaringer, som videnskaben kan bidrage med. Durkheims sociologi kan i den forstand ses som en oversættelse af religiøse erkendelser - herunder teologiske. Durkheims holdning er således, at nok er der 'noget evigt i religion'; men dens udtryk anno 1914 er utidssvarende, og 'for at sprede eller blot vedligeholde religion, må man retfærdiggøre den - dvs. man må opbygge en teori om den' (Durkheim 1965, 615). ${ }^{10}$ Denne metodiske indfaldsvinkel, som man måske kan kalde 'sympatetisk', bliver særligt tydeligt i "L'avenir de la religion". Durkheim ønsker, at de to grupper fra hver deres udgangspunkt skal søge ind mod et neutralt midtpunkt. Man kunne betragte det som en form for 'metodisk agnosticisme'. For den første gruppe forsøger han at fremstille religion som baseret på virkelige kræfter, der kan forstås og forklares. For den anden gruppe taler han "et andet sprog" og understreger, at religionsteorier tager afsæt i en "religiøs virkelighed". Begge er citater hentet fra den nedenstående oversættelse. Det afgørende er i denne sammenhæng, at Durkheims syn på forholdet mellem tro og viden optræder som forholdet mellem de to perspektiver af et fiksérbillede. På den ene side er religion individers virkelige, religiøse erfaringer, og på den anden side er religion virkelige, sociale kræfter. Disse overvejelser peger i retningen af et lidt uoverkommeligt tema, som ikke desto mindre er mere end relevant: Durkheims forhold til Kant. Det er en kendt sag i forskningen, at Durkheim havde et udestående med Kant - han ville præcisere den kantianske filosofi. Meget forenklet er sagen den, at Durkheim forstår social klassificering, hvis første udtryk er inddelingen af verden i de to modstridende kategorier helligt og profant, som fornuftens udspring. Det vil med andre ord sige, at fornuften udspringer af religion. Derfor kan Durkheim afvise, at der skulle være et modsætningsforhold mellem på den ene siden videnskab og på den anden side religion og moral. Han opfatter dem derimod som forskellige modi af menneskelig aktivitet, som udspringer af den samme kilde. Den erkendelse gjorde Kant sig også, da han lod den rene og den praktiske fornuft udgøre to forskellige aspekter af den sammen åndsevne. Det medgiver Durkheim også. For ifølge Kant forenes de to typer fornuft i deres egenskab af at tænke på det generelle og universelles præmisser. For Durkheim indebærer dette, at såvel videnskab som religion forudsæt-

10 På dette punkt nærmede Durkheim sig samtidige (protestantiske) positioner inden for fransk religionsforskning som fx Jean Réville, der mente, at forskningen i religioner kunne tilbyde sig som en art (meta)religion og i sig selv have en "positive religious value, and not merely the negative demythologizing value" (Strenski 2006, 212). Hvad Durkheim imidlertid ikke kunne være enig i, var protestanternes teleologiske fremhævelse af kristendommen som den finale og bedste religion og dermed som indirekte som skabelon for denne metareligion. 
ter, at individet er i stand til at træde uden for sig selv og sine partikulære eksistensforhold for at deltage i et overordnet (ideelt) 'ikke personligt liv'. Dette synspunkt korresponderer for så vidt med Kant; men hvad Kant ikke kunne forklare var, hvorfra evnen til at tænke, selve fornuften, kom fra. Durkheim vil på dette punkt 'historisere' Kant og forklare, hvorfra i mennesket udvikling fornuften opstod. Det gjorde den i forsamlingen og ritualet. Heri beror nemlig individers evne til at træde ud over deres partikulære-individuelle perspektiv. I den forstand baserer den religiøse erfaring sig grundlæggende på den samme kognitive evne, som er socialt funderet. Hertil kommer, at den religiøse refleksion med forskellige grader af tydelighed kan siges at udtrykke eller agere på præmisserne af netop dette forhold, hvorfor det snarere er religionsforskeres opgave at oversætte de religiøse erkendelser end at afsløre bagvedliggende mekanismer. Milbank er således på rette spor, når han beskriver Durkheims sociologi som en slags teologi. Og hermed når vi til oversættelsen.

\section{Oversættelse af "Religionens fremtid"}

Mine damer og herrer, det er mig en ære at få lejlighed til at tale for Dem i dag. M. Abauzit blev opmærksom på, at jeg kun havde mulighed for at deltage i begyndelsen af arrangementet og spurgte mig, om jeg ville sige et par ord nu. På grund af den korte forberedelsestid bliver mit oplæg desværre improviseret; men det er selve indholdet til gengæld ikke. Jeg skal forsøge ikke at foregribe det emne, som M. Belot vil behandle i aften. Jeg takker ham for at lade mig tale først. M. Belot vil gennemgå en bog om bestemte former for religiøst liv, som jeg udgav for nyligt. Derfor vil jeg her sige et par ord om den måde, jeg håber, at man vil opfatte og drøfte den på. Da vores forsamling består af to grupper - fritænkere på den ene side og 'frie troende' på den anden - ønsker jeg at tale til disse enkeltvis.

Jeg vil først henvende mig til gruppen af fritænkere; mennesker, som forholder sig åbent og frisindet til enhver form for dogmer - også de dogmer, som har været kernen af 'den fri tanke'. For at få Dem til at forstå, hvad der er specielt ved mine idéer, vil jeg gøre dem opmærksom på en besynderlighed ved det religiøse liv. Besynderligheden er ikke ukendt for den troende. Men fritænkeren er ikke altid tilstrækkeligt bevidst om den. Ikke desto mindre inkarnerer netop denne besynderlighed det religiøse livs sande karakter.

Mange tænkere, som vil forklare religion rationelt, har opfattet den som et system, der udelukkende eller primært består af forestillinger: et system af repræsentationer [représentations], som udtrykker fænomener som søvn, drømme, sygdom, død eller de store naturdramaer. Når man udelukkende eller hovedsageligt fokuserer på dette aspekt ved religion, virker det ikke usandsynligt, at den skulle kunne være frembragt af et enkelt individs tankevirksomhed. Der er ingen tvivl om, at disse repræsentationer kan være urovækkende; de har en slags mystisk karakter, som foruroliger os. På den anden side ved vi af erfaring, at den menneskelige bevidstheds frembringelser er så 
varierende, forskelligartede, mangfoldige og kreative, at det ikke forekommer at være et problem at betragte de religiøse repræsentationer som et produkt af netop denne bevidsthed. Vi er villige til på forhånd at acceptere, at tanken har været i stand til at skabe alle disse undere ud af intet. Men selvom religiøse forestillinger måske hver især besidder specielle karaktertræk, så er det netop mod disse som gruppe, vi må vende os, hvis vi skal forstå, hvad der er karakteristisk ved religion.

For religion er ikke kun et system af forestillinger. Det er først og fremmest et system af kræfter. Det menneske, som lever i overensstemmelse med en religion, er ikke alene et menneske, som opfatter verden på en bestemt måde, et menneske som ved noget, har indsigt i noget, som andre ikke har indsigt i. Det er først og fremmest et menneske, som føler en kraft inde i sig selv. Denne kraft er det ikke bevidst om til hverdag, men kun når det befinder sig i den religiøse tilstand. Det religiøse liv rummer meget specielle kræfter. Jeg kan ikke gennemgå dem udtømmende ved denne lejlighed, men, som man siger, er dette kræfter, som kan flytte bjerge. Det skal forstås på den måde, at et religiøst menneske tror, at det participerer i en kraft, som dominerer det, men som samtidig opretholder og hæver det over dets naturlige indskrænkninger. Dette menneske føler sig således styrket og bedre rustet til at klare tilværelsens udfordringer og besværligheder. Det føler sig endda i stand til at påvirke naturens gang.

Denne følelse har været udbredt gennem menneskehedens historie, og den er for grundlæggende og genkommende til at være en illusion. En illusion kan ikke på denne måde have en holdbarhed igennem århundreder. Det er med andre ord en afgørende pointe, at denne kraft, som mennesket føler, faktisk også eksisterer. Det betyder, at fritænkeren, som vil forklare religion på baggrund af dens naturlige årsager uden at henvise til almene opfattelser udtrykt i dagligsproget, må overveje spørgsmålet på følgende måde: hvor i sanseverdenen udspringer disse kræfter, som dominerer og samtidig opretholder det religiøse menneske?

Det er indlysende, at menneskets evne til at opfatte disse kræfter, denne tilstrømning af liv, ikke er baseret på kognitive evner og forsøget på at forklare bestemte naturfænomener. Kræfter af den slags kan ikke være opstået som fejlagtige repræsentationer af søvn eller død. Men det er på den anden side heller ikke sandsynligt, at de spektakulære naturkræfter i sig selv skulle have frembragt dem.

Det har ellers været udgangspunktet for det hidtil bedste forsøg på at forklare religion rationelt. Men naturkræfter er kun naturkræfter; derfor kan de ikke trænge ind i mig. Jeg kan se dem udefra; men de påvirker mig ikke, og de har ingen indflydelse på mit indre liv. Jeg føler mig ikke stærkere, bedre i stand til at møde skæbnen eller mindre underlagt naturen, fordi jeg ser flodens strøm, afgrøder skyde op og stjerne i 
deres bane. Jeg kan kun føle moralske ${ }^{11}$ kræfter, og det er kun dem, jeg kan opleve som en fordring og en trøst. Disse moralske kræfter må være virkelige, de må virkelig være i mig, for selve følelsen af trøst og afhængighed er ikke en illusion.

Med denne bestemmelse fremstår problemet relativt simpelt. For at forklare religion, for at gøre den rationelt forståelig - og det er, hvad fritænkeren ønsker at gøre må vi finde en kilde til disse kræfter. Vi må finde noget, som vi kan opfatte med vore menneskelige åndsevner gennem observation, og som samtidig giver adgang til de energier, som formidles gennem individets erfaring, men som er større og mere omfattende. Jeg spørger mig selv, om denne kilde kan findes noget andet sted end i det helt specielle liv, som frigøres i en forsamling af mennesker? Vi ved af erfaring, at når mennesker er forsamlet, når de lever et fælles liv, vil selv den omstændighed, at de forsamles, udløse exceptionelt intense kræfter, som påvirker dem, opløfter dem og giver dem en livskvalitet, som er ukendt for dem i deres respektive daglige gøremål. Under den kollektive entusiasme bliver de undertiden grebet af et positivt delirium, som får dem til at gøre ting og opføre sig på måder, som ligger langt fra deres normale adfærd.

Jeg har ikke mulighed for her at præsentere de analyser og kendsgerninger, som jeg har baseret denne fundamentale tese på. Jeg vil begrænse mig til at advare dem blandt publikum, som ikke har læst mit arbejde, om at denne metode til at forstå og forklare religion, skønt den ikke påberåber sig at præsentere en bevist sandhed, på den anden side heller ikke er baseret på ren spekulation [dialectique]. Der er ikke tale om en abstrakt og ren filosofisk hypotese. Men uafhængigt af kendsgerningerne og den historiske observation har teorien allerede inspireret og angivet en fordelagtig retningslinje for mere end ét forskningsprojekt: Den har allerede tjent til at fortolke adskillige fænomener i forskellige religioner. Den er med andre ord blevet stillet for erfaringens prøve og har bevist sin levedygtighed.

Jeg vil ikke her forsvare min idé, som De senere vil få fremlagt og lejlighed til at diskutere frit og upartisk. Formålet med min tale er at forberede Dem på den fremstilling og gennemgang, De kommer til at høre. Det er ikke passende for mig at foregribe denne gennemgang. Kort og godt beder jeg fritænkeren om at gå til emnet religion i samme ånd som den troende. Det er en betingelse, hvis han ønsker at forstå. Lad ham føle, som den troende føler, for sådan som det føles for den troende, sådan er det i virkeligheden. Enhver, som ikke medbringer en form for religiøs følelse til sit forskningsarbejde, vil derfor ikke kunne tale om religion! Det ville være som en blind mand, der udtaler sig om farver. For den troende er grundlaget for religion ikke en plausibel eller forførende hypotese om mennesket og dets skæbne. Det som binder ham til sin

11 Hos Durkheim betyder 'moral' ikke 'god', men 'åndeligt', 'immaterielt'; modsætningen til moral er ikke umoral, men den fysiske-biologiske verden (jf. Karen Fields indledning til 1995-oversættelsen af FE p. iv). 
tro, er, at den er en integreret del af hans selvbillede. At opgive denne tro ville derfor være som at opgive en vital del af ham selv. Det ville være en reduktion, en decimering af hans vitalitet - et fald i hans moralske temperatur.

Kort sagt er det karakteristiske ved religion den dynamogeniske [dynamogénique] indflydelse, den øver på bevidsthederne [les consciences]. At forklare religion er at forklare denne indflydelse.

Jeg vil nu henvende mig til den fritroende, det menneske, som skønt han tilhører en religion, skønt han endog følger de konfessionelle forskrifter, alligevel forholder sig så åbent som muligt til dem. Til ham vil jeg tale et andet sprog.

Jeg vil bede ham bære over med mig. Jeg mener, at den tilgang til emnet religion, jeg taler for, fortjener overbærenhed. Men dog er det meningsløst for mig at forsøge at nå den troende, der urokkeligt følger trosregler og dogmer og mener at kende den endegyldige sandhed om religion. På den anden side vil der være grundlag for samarbejde med den slags troende, som mener, at trosregler kun er foreløbige udtryk, som holder og kan holde i et bestemt tidsrum. Det vil sige: Hvis han kan være enig i, at alle disse regler er uperfekte udkast, at det afgørende ikke er ordlyden, men den virkelighed, som gemmer sig bag dem - og som de alle udtrykker på en mere eller mindre upræcis måde - og at det som følge heraf er nødvendigt at se under overfladen for at forstå den underlæggende kraft.

Vi må være åbensindede og som et eksperiment praktisere en art kartesiansk tvivl; uden dog at gå så langt som til at afvise de trosregler, som vi bekender os til, må vi glemme dem provisorisk. Men vi forbeholder os retten til at vende tilbage til dem på et senere tidspunkt. Da er vi ikke længere i fare for at begå de fejl og den uretfærdighed, som bestemte troende, der har opfattet min måde at fortolke religion på som grundlæggende irreligiøs, har haft tendens til.

Man kan ikke formulere en tilfredsstillende fortolkning af religion, som er fundamentalt irreligiøs. En sådan fortolkning benægter det fænomen, som det forsøger at forklare. Intet ville stå i større modsætning til den videnskabelige metode. Måske kan man forstå dette fænomen på en anden måde. Måske er det slet ikke til at forstå. Men det kan ikke benægtes.

Når vi undgår at identificere religion med et specifikt dogme, bliver det tydeligt, at der i stedet er tale om en helhed af forestillinger, som har den virkning at hæve mennesket over sig selv - som sætter mennesker i stand til at hæve sig over dagligdagens almene overvejelser og bekymringer og giver adgang til en eksistens, som i værdi og værdighed overgår den, det fører til hverdag. Den doktrin, De senere i dag kommer til at høre om, og hvis eksistentielle pointer jeg for kort tid siden skitserede for Dem, baserer sig på den antagelse, at der over samtlige dogmer og religiøse konfessioner løber en kilde til det religiøse liv, som er ligeså gammel som menneskeheden, og som aldrig tørrer ud. Den er resultatet af individers bevidsthedssammensmeltninger, af fællesskabet, som er funderet i fælles forestillinger, af samarbejdet omkring konkrete 
opgaver, af den moralsk styrkende og stimulerende virkning, som fællesskaber har på deres medlemmer.

Måske kan vi blive enige om dette forslag? Der vil sandsynligvis være nogle af Dem, som tænker, at dette religiøse liv ikke er tilstrækkeligt, at det er et, som er højere og som har en ganske anden oprindelse? Men det er dog noget at være i stand til at anerkende, at der i os og uden for os eksisterer religiøse kræfter, som er afhængige af os for at eksistere - kræfter, som vi ikke kan undgå at fremkalde, når vi forsamles og tænker, føler, handler i fællesskab?

For kort tid siden lyttede vi til en taler, ${ }^{12}$ der som en pompøs profet pegede mod himlene, som han mente var ved at blive rømmet. Han opfordrede os til at vende vores opmærksomhed mod jorden og det materielle. Det vil sige, at vi bør varetage vore økonomiske interesserer efter bedste evne. Denne læresætning er blevet kaldt ugudelig; jeg anser den for fejlagtig. Der er ingen grund til bekymring. Himlene vil aldrig blive endegyldigt affolket, for det er os selv, der bebor dem. Guderne er projektioner, forstørrede billeder af os selv. Så længe der findes menneskelige samfund, vil de tjene og underkaste sig deres idealbilleder af sig selv.

Er det ikke rimeligt at betragte min sociale opfattelse af religion som animeret af den religiøse ånd, som det ville være uvederhæftigt ikke at anerkende?

For at udfolde mine synspunkter må vi forsøge at forestille os, hvordan fremtidens religion vil gestalte sig. Det vil sige en religion, som er mere bevidst om sin sociale oprindelse. Man må naturligvis være forsigtig og gøre sig klart, at det ville være formålsløst at forsøge at forudse det præcise udtryk, en sådan religion måtte få. Det, man imidlertid kan sige noget om, er de sociale kræfter, som vil føde den.

Hvis vores religiøse liv i dag er ved at sygne hen, hvis de forbigående vækkelsesbevægelser, vi er vidner til, altid synes overfladiske og kortlivede, skyldes det ikke, at vi har vendt os bort fra en bestemt konfessionel tro. Det skyldes derimod, at vores evne til at skabe idealer er blevet svækket, og at vore samfund befinder sig i en fase af alvorlig sindsbevægelse. I en vis forstand bør samfundene være stolte af denne forandring, som de er i færd med at undergå. Den udspringer af den omstændighed, at samfundene efter den periode af fred og ligevægt, som de kunne leve i, nu er nødt til at forny sig. Under møje og besvær må de forsøge at genopdage sig selv. De gamle idealer og guder, som førhen var indbegrebet af samfundet, er døende: De passer ikke til de nye krav og forventninger, som er opstået. De nye idealer, som vi har brug for til at udstikke retningen for vores liv, er endnu ikke født. Vi befinder os med andre ord i en overgangsperiode, en periode af moralsk kulde. Det er baggrunden for de mange krisetegn, vi til stadighed foruroliges af og bedrøves ved.

Men hvem føler ikke - og det er denne omstændighed, som må berolige os - hvem føler ikke, at der i samfundets dyb er et intenst liv i gæring, som forsøger at bryde frem

12 Durkheim refererer muligvis til Gustave Belot, men det står lidt uklart. 
og som til sidst vil lykkes med det? De eksisterende trosregler kan ikke tilfredsstille os. Vi stræber efter en højere retfærdighed. De skjulte forsøg vil en dag blive mere selvbevidste og oversætte sig selv til klare trosregler, som mennesker kan forsamles om og som vil udgøre midtpunktet for krystalliseringen af nye forestillinger. Selve indholdet af disse forestillinger er det imidlertid formålsløst at forsøge at forudse. Vil de forblive generelle og abstrakte? Vil de være forbundet til personlige væsener, som vil inkarnere og repræsentere dem? Det beror på den tilfældige, historiske udvikling, som man ikke kan sige noget om på forhånd.

Det afgørende er, at man under den moralske kulde, som hersker på overfladen af vores kollektive liv, fornemmer de varmekilder, som alle samfund bærer i sig. Man kan gå et skridt længere: det er blandt de folkelige lag, disse kræfter ved at formere sig.

Mine damer og herrer, vi er nødt til at vende os til den tankegang, at menneskeheden på denne jord er overladt til sig selv og at den selv må forme sin skæbne. Tankegangen har vundet terræn op gennem historien og jeg tvivler på at den vil tabe terræn i fremtiden. For det menneske, som plejer at forestille sig de kræfter, det støtter sig til, som superhumane entiteter, kan det virke foruroligende. Men hvis det lykkes det at overbevise sig selv om, at menneskeheden i sig selv kan forsyne det med den støtte, det har brug for, er der så ikke noget højst betryggende ved denne udsigt? For de ressourcer, det påkalder sig, vil være højst tilgængelige.

\section{LITTERATUR}

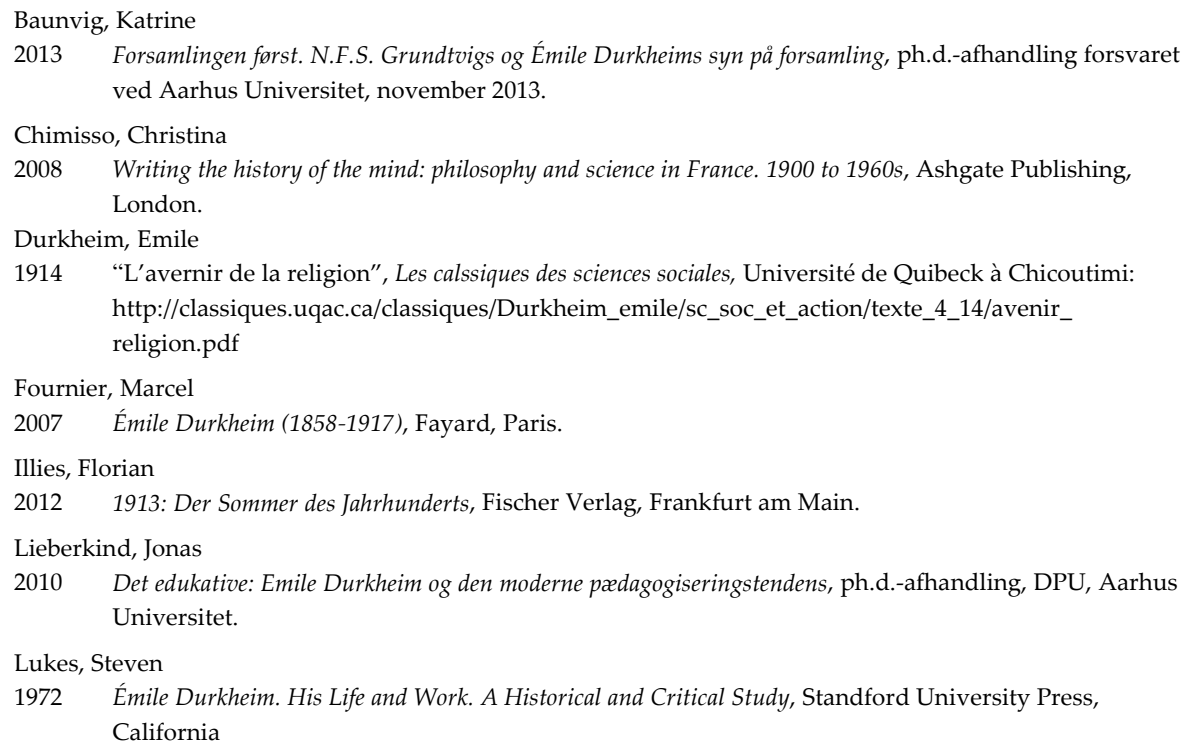


Lundager Jensen, H.J.

2003 "Roy Rappaport: Ritual and Religions in the Making of Humanity", i Religionsvidenskabeligt Tidsskrift 43, Aarhus Universitetsforlag, Aarhus.

2005 "Moses og bodysnatchernes invasion (Durkheim, cognition og Deuteronomium)", Religionsvidenskabeligt Tidsskrift 47, Aarhus Universitetsforlag, Aarhus.

2008a "Religion, hukommelse og viden - Jan Assmann, med udblik til Durkheim, Rappaport og Augustin", i Religionsvidenskabeligt Tidsskrift 52, Aarhus Universitetsforlag, Aarhus.

2008b "Kognition og kultur", i Religionsvidenskabeligt Tidsskrift 53, Aarhus Universitetsforlag, Aarhus.

2009 "Gammel Testamente ved Det Teologiske Fakultet ved Aarhus Universitet", i Religionsvidenskabeligt Tidsskrift 54, Aarhus Universitetsforlag, Aarhus.

Neumann, Iver B.

2011 Tilbake til Durkheim: Staten og antropologien, Olso Universitetsforlag, Oslo.

Olesen, Søren Gytz

2010 Pædagogik i sociologisk perspektiv : en præsentation af Karl Marx \& Friedrich Engels, Émile Durkheim, Michel Foucault, Niklas Luhmann, Pierre Bourdieu, Jürgen Habermas, Thomas Ziehe, Anthony Giddens, ViaSystime, Aarhus.

Pickering, W.S.F

2002 Durkheim Today, Berghahn Books, London.

2010 “Gustave Belot, Critic and Admirer Of Emile Durkheim: An Introduction”, Durkheimian Studies 16, 109-124.

Ranulf, Svend

1939 "Scholarly Forerunners of Fascism", i Ethics 50 (1), 16-34, University of Chicago Press

Stedman Jones, Susan

2001 Durkheim Reconsidered, Polity Press, London.

Strenski, Ivan

2006 The New Durkheim, Rutgers University Press, New Brunswick.

Sørensen, Asger

2012 "Durkheim: The goal of education in a democratic state is autonomy" in: Peter Kemp \& Asger Sørensen, eds., Politics in Education, edt., LIT Verlag Dr. Wilhelm Hopf, Berlin.

Zweig, Stefan

1942 Die Welt von Gestern, Fischer Verlage.

Katrine Frøkjær Baunvig, ph.d., postdoc

Grundtvig Centeret, Aarhus Universitet 